University of Louisville

ThinkIR: The University of Louisville's Institutional Repository

Faculty Scholarship

Winter 2019

\title{
Black Hawk in Translation: Indigenous Critique and Liberal Guilt in the 1847 Dutch Edition of Life of Ma-ka-tai-me-she-kia-kiak
}

Frank Kelderman

University of Louisville, frank.kelderman@louisville.edu

Follow this and additional works at: https://ir.library.louisville.edu/faculty

Part of the American Literature Commons, English Language and Literature Commons, and the Indigenous Studies Commons

Original Publication Information

Kelderman, Frank. "Black Hawk in Translation: Indigenous Critique and Liberal Guilt in the 1847 Dutch

Translation of Life of Ma-ka-tai-me-she-kia-kiak." 2019. Studies in American Indian Literatures 31(3-4): 58-83.

ThinkIR Citation

Kelderman, Frank, "Black Hawk in Translation: Indigenous Critique and Liberal Guilt in the 1847 Dutch Edition of Life of Ma-ka-tai-me-she-kia-kiak" (2019). Faculty Scholarship. 459.

https://ir.library.louisville.edu/faculty/459

This Article is brought to you for free and open access by ThinkIR: The University of Louisville's Institutional Repository. It has been accepted for inclusion in Faculty Scholarship by an authorized administrator of ThinkIR: The University of Louisville's Institutional Repository. For more information, please contact thinkir@louisville.edu. 


\section{Black Hawk in Translation}

Indigenous Critique and Liberal Guilt in the 1847

Dutch Edition of Life of Ma-ka-tai-me-she-kia-kiak

FRANK KELDERMAN

In 1846 Rinse Posthumus, a Protestant country pastor in the north of the Netherlands, received from a friend a copy of Life of Ma-ka-tai-me-shekia-kiak, the as-told-to autobiography of the Sauk warrior Black Hawk. First published in Cincinnati in 1833, the Life was a best seller in the United States, but it was unfamiliar to Posthumus, who lived in a small village near the North Sea in the province of Friesland (Frisia). Over the course of the year, he studied Back Hawk's life story and began a translation of the text for Dutch readers, which he published in the city of Leeuwarden in 1847 as Levensgeschiedenis van Ma-ka-tai-me-she-kiakiak, of Zwarte Havik. If Black Hawk can be regarded as the author of his autobiography, this makes Posthumus's text the first foreign translation of a book-length work of Native American literature. ${ }^{1}$

Posthumus's edition did not cause much of a stir. Years later, the Dutch anticolonial writer Eduard Douwes Dekker mentioned the book as an "important" work (Multatuli 50), but no subsequent editions of the translation were published, nor has there been any commentary on the text by literary historians. Nevertheless, Levensgeschiedenis van Zwarte Havik sheds new light on the role of Indigenous writing in a transatlantic print culture in which the representation of American Indians generated popular entertainment, theories of government, and philosophies of universal history. In Britain, the circulation of American Indian literature came on the heels of a wealth of writings about Indigenous people in periodicals and newspapers, as well as "anthropological studies, works of racial science, and missionary narratives" (Flint 3). There was a continental European dimension to this story as well, and since the early nineteenth century the representation of Indianer held a prominent place especially in the German cultural imagination 
(Bolz; Zantop; Penny; King). But as a growing number of studies has shown, the role of Indigenous people in what Jace Weaver terms "the Red Atlantic" was not merely to provide symbolic representations of Native presence: their writings, performances, diplomacy, and protests inflected the very currents of modern political and intellectual thought (Weaver; Flint; Lyons). Extending these transatlantic dialogues to a Frisian-Dutch print culture, Rinse Posthumus's translation of the Life not only catered to a widespread ethnological interest in Native American culture in Europe but also brought Black Hawk's critique of settler expansion into political debates about state power that had local and transnational implications.

This essay is about what happened to Black Hawk's story in translation. Annotated by a rural pastor in the province of Friesland, Levensgeschiedenis connects Black Hawk's account of Indian removal in the American Midwest to a region that has been marginal to the history of cultural exchange in the Atlantic world. In what follows, I consider Rinse Posthumus's role as translator and editor, tracing how his theological commentary builds on Enlightenment assumptions about race and linguistic difference even as it carries out a universalism that validates Indigenous cultural traditions. But I also argue that his editorial work amplifies a critical current in Black Hawk's text about the relation between settler colonialism and the role of government, which intersected with nineteenth-century debates about political liberalism and immigration to North America. Posthumus witnessed the economic decline in the northern Netherlands in the 1840s, and his edition of the Life resonates with concerns about agricultural crises in Europe and the population movements of the mid-nineteenth century. By annotating Black Hawk's account of Sauk traditions and Indigenous dispossession, Posthumus gives voice to his political commitment to liberalism during a time of economic depression and revolutionary energy in the Netherlands. Since these pressures gave rise to a peak in Dutch immigration to the American Midwest-including the very lands that were opened up for settlement after the Black Hawk War (1832) his commentary in Levensgeschiedenis negotiates a politics of liberal guilt over the intertwined histories of European migration and Sauk dispossession. Tracing these connections in the interplay between text, translation, and paratext, this essay explores the transatlantic movement of an Indigenous critique of settler colonialism. 
FROM BLACK HAWK'S LIFE TO ZWARTE HAVIK'S

With the Dutch translation of Black Hawk's Life of Ma-ka-tai-me-shekia-kiak, Rinse Posthumus added a continental European dimension to the publishing history of one of the most important works of nineteenth-century Native American literature. In his autobiography, the Sauk warrior Black Hawk (1767-1838) recounts how an 1804 treaty with the Americans defrauded the Sauk Nation of significant lands in present-day Illinois and Iowa and how he challenged the validity of the treaty and the subsequent land cessions. As white homesteaders flooded into the Rock River region, in present-day Illinois and Iowa, Black Hawk's resistance to the treaty system and settler encroachment was met with a violent response from the Americans, and in 1832 the conflict came to a head in what is known as the Black Hawk War. Over the course of fifteen weeks, the war took hundreds of American Indian lives and ended with the Battle of Bad Axe, a massacre during which settler volunteers killed American Indian women and children. After the war, the United States War Department held Black Hawk and four allied leaders in captivity and took them on a tour of eastern cities that made Black Hawk a "captive celebrity" through public spectacles and newspaper coverage (Helton 500; see also Scheckel 107-11). Returning to the Sauk Nation in 1833, Black Hawk told his life story to Antoine Le Claire, a French Potawatomi government translator at the Rock Island Indian Agency. It was published in book form by the newspaper editor John Barton Patterson; the first edition appeared in Cincinnati in 1833, and it was reprinted in Boston (1834 and 1845) and London (1836) (see also Round 160-65).

Extending this publication history, the 1846 Dutch edition is an anomaly in Native American literature because it amply predates other foreign translations of books by American Indian authors. Despite the widespread European interest in Native cultures, the works of William Apess (Pequot) and George Copway (Ojibwe) did not appear in translation on the European continent in the nineteenth century, although pirated adaptations of the Cherokee author John Rollin Ridge's novel The Life and Adventures of Joaquín Murrieta (1854) were translated into French and Spanish in the 1880 os (Parins 107). But it was not until the early twentieth century that the first significant body of foreign trans- 
LEVRSGESCHIRDRIS

vas

MA-KA-TAI-ME-SHE-KIA-KIAK,

or

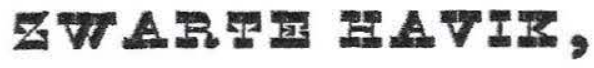

OPPERHOOFD

VAN DEN

STAM DER SAC-INDIANEN

IN

Moot-Amextika, 13

MET BEN BERIGT VAN DE GODSDIENSTIGE

DENKWIJZE, ZEDEN EN GEBRUIKEN,

VAN DIEN STAM;

TOLY DER SAC- EN FOX-INDIANEN, EN 18

DOOR DEZEN IN HET ENGELSCH

OVERGEBRAGT.

IN HET NEDERLANDSCH VERTAALD EN MET

EENIGE AANMERIINGEN YOORZIEN

DOOR

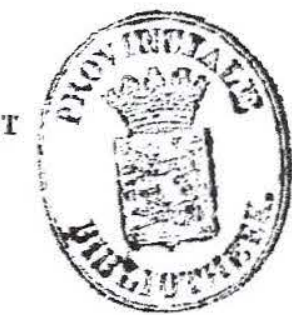

20

21

22

23

R. POST HUMUS。

J. H. HALBUR: $\sim$ MA, 28

LEEUWARDEN,

D. MEINDERSMA, Wz.

1847.

Fig. 1. Title page of Levensgeschiedenis van Ma-ka-tai-me-she-kia-kiak, of Zwarte

Havik (Leeuwarden: D. Meindersma, 1847), Tresoar, Leeuwarden, the Netherlands.

The full title translates as "Life history of Ma-ka-tai-me-she-kia-kiak, or Black Hawk, chief of the tribe of Sac Indians in North America, with an account of the 
lations of American Indian writers appeared, propelled by the popular Wild West shows that traveled across Europe between 1890 and 1914 (Bolz 484). Charles Alexander Eastman's (Santee Dakota) Indian Boyhood was published in German as Ohijesa in 1912, followed by German translations of Eastman's Old Indian Days in 1920 and Luther Standing Bear's (Sicangu and Oglala Lakota) My People, the Sioux ten years later (484). Before the twentieth century, the most significant works about Native Americans in foreign translation were authored by non-Native commentators, such as the travel accounts of George Catlin and Prince Maximilian zu Wied-Neuwied and Johann Georg Kohl's ethnology of the Ojibwe people on Lake Superior.

The translator of Levensgeschiedenis, Rinse Posthumus (17901859), was a Reformed pastor whose poems, books, and pamphlets take a central place in the literary history of Friesland, one of the two northernmost provinces of what was since 1815 the Kingdom of the Netherlands. Born in Ternaard, a Frisian village near the coast of the North Sea, he was the son of a grain farmer-also named Rinse Posthumus-who served as a local justice of the peace. Posthumus studied classical languages early in life while working on the family farm and later studied theology at the University of Groningen, where in 1813 he advanced to his kandidaats diploma (the equivalent of a bachelor's degree). Two years later, he became a pastor in the Reformed Church (Hervormde Kerk) in Waaxens, a village of less than two hundred inhabitants in the province of Friesland, where he lived for the remainder of his life (Wumkes 988). One of his contemporaries remembered Posthumus as a sometimes "unaffable" (ongezellig) person who lived a sober and rather isolated life in a "scattered rural municipality" where his work as a scholar depended mostly on "a curated library, the best foreign monthlies, and the newspapers" (Halbertsma 5, 31; translation mine). Posthumus published dozens of volumes of political, literary, and theological writings, including a critique of the governance of the Reformed Church (Brief, 1831) and a tract on poverty in the Netherlands (Over de al te groote armoede en verarming in Nederland, 1846). He had an abiding interest in the language and culture of the Frisians, a Germanic people along the North Sea coast of the Netherlands and Germany who speak a variety of Frisian dialects. He published Romantic poems in the West Frisian dialect (Prieuwcke fen Friesche Rijmmelarije, 1824) and translated three of Shakespeare's plays into West Frisian: Julius 


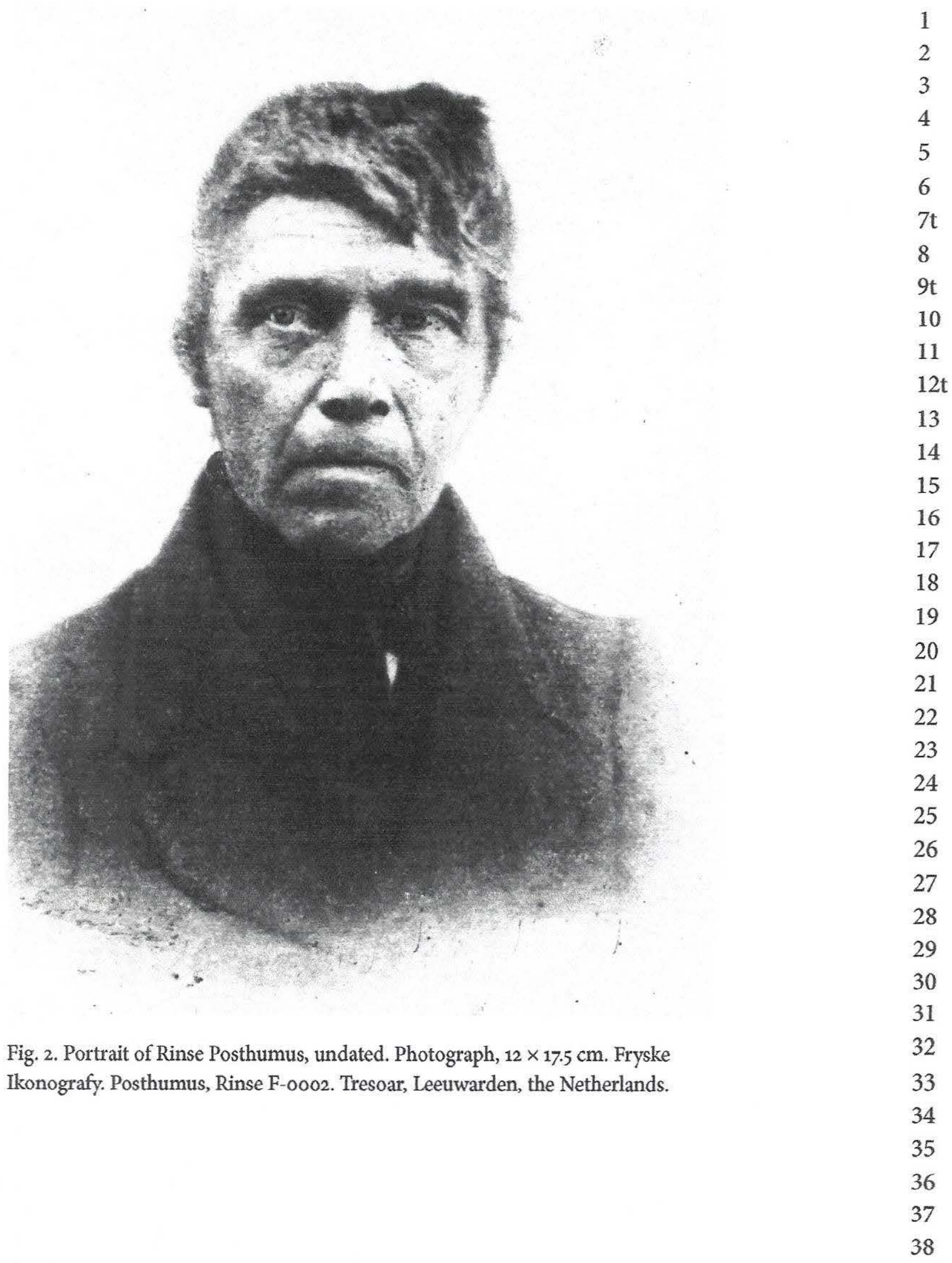


Caesar (1829), The Merchant of Venice (1829), and As You Like It (1842). In 1827 he was a founding member of a scholarly society that fostered a movement of Frisian cultural nationalism against the consolidation of Dutch national identity in the nineteenth century (Kuiken 184). Under its auspices, Posthumus traveled to the German region of Saterland for a study on local Frisian culture (Posthumus and Hettema, Onze reis naar Sagelterland). His commitment to folk culture was an important bedrock of a Frisian ethnolinguistic nationalism that he carried out most explicitly in an 1840 tract titled Een woord ter opwekking van den volksgeest in het zwijgend Friesland (A word to awaken the spirit of the people in the silent Friesland). This work is a reminder that the ethnological interest in American Indians had a counterpart on the European continent, where the rise of the nation-state brought about a heightened interest in local folk cultures.

If northern Friesland and the Sauk homelands seem like worlds apart, the story of how Black Hawk's narrative ended up in the hands of a small-town Frisian pastor bespeaks the intertwined histories of Dutch immigration and settler colonialism in North America. Although the Life had been republished in London in 1836, Posthumus only learned about it ten years later when he received a copy of the first edition from his friend Klaas Janszoon Beukma, a well-to-do grain farmer who had immigrated to the United States in the mid-183os. Beukma came from the adjacent province of Groningen, where he led a movement of northern farmers to protest the new taxes imposed by King William I after the Belgian Uprising of 1830-31. When these taxes contributed to a collapse in the grain trade, he immigrated to the United States and settled in Lafayette, Indiana, before eventually moving to New Jersey (Breuker 13-14; Krabbendam 204). ${ }^{2}$ These same political and economic pressures led to a surge in migrations of Dutch farmers to the American Midwest in the 1840 , and it is likely that the publication of Levensgeschiedenis, which is Posthumus's only translation of an American work, was motivated by an increased interest in transatlantic immigration. Although the number of Dutch settlers in the United States never reached the same level as those from other western European countries, 1846 and 1847 were in fact two peak years for immigration from the Netherlands in the nineteenth century (Krabbendam 4). And the northern provinces of Friesland and Groningen were among the three provinces that had the highest number of immigrants, many of whom settled in Michi- 
gan, Illinois, and Iowa $(7,9)$. Notably, the rise in Dutch migration to the

American Midwest was part of a wave of settlement that depended on

the removal of the Sauk and Meskwaki people from their homelands.

Indeed, by the time that eight hundred Dutch settlers arrived in Marion

County, Iowa, in 1847 (Swierenga 197), the US government had recently

completed the removal of the Sauk and Meskwaki people from that very

Given the surge in immigration in the mid-1840s, Levensgeschiedenis 8

likely catered to a wider demand for information about the American $9 \mathrm{t}$

Midwest. In this respect, the edition reads in part as an informational volume about the geography of the Illinois-Iowa region and how large 10 tracts of the Midwest were opened up to white settlement after the Black Hawk War. To this effect, Posthumus's translation stays close to the 1833 text, and his introduction and endnotes do not sensationalize Black Hawk's account; Posthumus remarks that "I have made faithfulness my main goal, perhaps at the expense of fluidity" (Levensgeschiedenis xv). ${ }^{3}$ Throughout the book, Posthumus translates the name Black Hawk literally as Zwarte Havik and "Indians" as indianen (he does not capitalize the word). Posthumus's role as translator is most visible when he uses appositive translations to offer both the original English term and the Dutch translation. For instance, he glosses culturally and geographically specific terms like "prairie" (vlak grasland), "wampum" (vrede-gordeI), and "tomahawk" (oorlogsbijl), as well as more general terms like "fences" (omheiningen van palen) and "bluffs" (hoog oeverland). In some cases, Posthumus clarifies the meaning of place-names, as when he translates Portage des Sioux as overvoerplaats der Sioux. Perhaps the most significant act of translation is typographical. The original volume frequently uses italics to accentuate the dynamics of Black Hawk's oral delivery, but Posthumus renders these emphases in regular font, thereby downplaying the performative dimensions of the source text.

In the absence of international copyright law, Posthumus published the volume under his own auspices with the publishing house of $D$. Meindersma in Leeuwarden. He added the ten-page "Foreword from the Dutch Translator" and nineteen pages of endnotes with moral and religious commentary on Black Hawk's text, often pointing out the hypocrisy of self-professed Christians. These annotations also give historical context by turning to Anglo-American letters, drawing on David Hume's Natural History of Religion (1757) to argue for the similarities 
between Sauk ceremonial practices and ancient religions. In addition, Posthumus consulted a Dutch translation of Jonathan Carver's Travels through the Interior Parts of North America (1778) to offer context about the history of the French and British Empires in North America, the treaty system, and Indigenous practices of hunting and warfare. This means that Levensgeschiedenis is also the first scholarly edition of Black Hawk's book, published more than a century before Donald Jackson's 1955 edition made the Life a key text in the canon of Native American literature.

\section{"JUST AS IT IS WITH US": LANGUAGE AND TEMPORALITY}

IN POSTHUMUS'S TEXTUAL COMMENTARY

As one of the earliest Native American autobiographies, Black Hawk's Life is now a fixture in studies of early Indigenous writing, and scholars have examined the book as a representation of masculine self-performance (Sweet), as a traditionalist critique of the territorial mappings of US Indian policy (Rifkin), and as part of a longer tradition of Native American elegiac expression (Krupat, "Patterson's Life"). Rinse Posthumus's Dutch edition underscores that the Life is also a book about the translation of Black Hawk's oral text. Like the 1833 edition, Levensgeschiedenis gives insight into the collaboration that produced Black Hawk's autobiography, as it reprints the prefatory materials in the original volume: a statement on the translation by the interpreter Antoine Le Claire; the editor John Barton Patterson's "advertisement" to the reader; and Black Hawk's dedication to General Henry Atkinson, the commander of the settler army during the Black Hawk War. The latter is included in Dutch and in a transliteration of the Sauk language, which presents a phonetic rendering of Black Hawk's words. ${ }^{4}$ Since the original volume does not include substantial information on the Sauk language, Posthumus comments that he does "not know what to make of it" but that the dedication may help readers "determine the origins, authenticity, and the degree of reliability" of his edition (Levensgeschiedenis xv).

Given his lack of insight into the Sauk language, Posthumus instead places the issue of translation in a more abstract philological debate on linguistic difference. He argues that the collaboration between Black Hawk, Le Claire, and Patterson was an encounter between what he calls 
a "little developed" Indigenous language and the "civilized" English 1 tongue: 2

The sensible and unprejudiced reader will see for themselves, how incredibly difficult here the task must have been of those by whose collaboration this life story came into being. For BLACK HAWK it must have presented problems, in his yet so little developed language, to express himself clearly and without interruption [verstaanbaar en aaneengeschakeld]. For the interpreter and publisher it must have been no less difficult to record the ideas of the chief, captured in such a flawed way in his imperfect language, and to record and reproduce them in their civilized language and draw them accurately, just as they had been given to them. (Levensgeschiedenis xii)

In this encounter between two radically different languages, Posthumus it difficult to translate Black Hawk's ideas accurately, since even his own "imperfect" language did not allow for the full expression of his ideas.

This ideologically fraught commentary attests to an Enlightenment philology in which Indigenous languages figured as a means to corroborate conjectures on the development of human civilizations. Linking language and race, the assumptions and misinterpretations of Enlightenment intellectuals about the development of Indigenous languages shaped broader ideas about Native people's literary capabilities (Harvey ries of an ancient and sacred essence" that could buttress theories of scientific and literary progress (Rivett 8). Starting from a similar premise, Posthumus suggests that any misunderstandings between Black Hawk and his interpreter testified not to the practical difficulties of translation

Posthumus's analysis of Black Hawk's text thereby attests to the 
trace such a developmental history directly through the representation of oral Indigenous speech acts on the page. To this effect he emphasizes the acts of both hearing and seeing to take in Black Hawk's narrative:

Here we hear and see a less developed member of our stock, a wild Indian from North America's woods, speak about his more civilized brothers and act with and against them. Here we see ... in what different forms man shows himself on this earthly stage and in what distinctly higher and lower rungs he has been placed to climb up from time to time. Here we hear from the mouth of a genuine child of nature an unadorned narrative of his life and pursuits and how he chased after further development and judged the actions of his white and more civilized brothers. (Levensgeschiedenis vii)

However, for Posthumus the theory of stadial development is only relevant insofar as it offers a framework to recognize "generality and uniformity" among the world's various peoples. Posthumus points out semiotic systems, beyond spoken or written language, that express a universal human nature across linguistic and cultural boundaries. In a pivotal moment early in the text, Black Hawk recounts his process of grieving after the death of his father: "Owing to this misfortune I blacked my face, fasted, and prayed to the Great Spirit for five years" (Black Hawk 15). Posthumus's endnote to this passage highlights a similarity between Sauk and European customs, noting that "black, the color of the night, is here also the symbol of grief and sadness just as it is with us" (130). By this logic, linguistic difference does not mark a fundamental human difference in Posthumus's commentary: "Here human nature may express itself in a more childlike and worldly [zinnelijk] manner than in more educated men. It is nonetheless the same nature, however different the form of its expression" (Levensgeschiedenis 130).

Given Posthumus's interest in Sauk ceremonial practices, both secular and religious, his introduction and endnotes partly validate the virtues of Indigenous cultural practices. Inspired by a Romantic ethos of folk culture, Posthumus resisted "any false pretense to civilization" that posed a threat to local cultures (Wumkes 988; translation mine). To be sure, his annotations to this effect are fraught with a Eurocentric assumption of cultural superiority. Commenting on Black Hawk's description of Sauk dances, Posthumus writes that they must be "rougher simula- 
tions of their actions in warfare and other occasions, rather than the natural and graceful movements according to music.... They are more like pantomimes ... to entertain themselves according to their capacity rather than to truly dance" (Levensgeschiedenis 138). But he immediately neutralizes his own judgment. "Enough," he adds; "everyone dances and sings in their own way: and should it meet its goal, which is recreation, then the manner in which it does so will matter less" (138). In moments like this, Posthumus's moral didacticism is directed against a disparagement of folk traditions, which he vigorously defended in the service of Frisian cultural nationalism.

Overwhelmingly, however, Posthumus locates a shared humanity in practices of religious worship. He suggests that the Sauk people's practice of fasting is seen as "penitence, or punishment" to appease the Great Spirit, "just as happens among people generally" (Levensgeschiedenis 131). And when Black Hawk mentions the traditional belief that the Great Spirit speaks to people in their dreams, Posthumus concludes that "man is and remains man everywhere; thus, we are all of equal pursuits" (131). Furthermore, he suggests that this belief in a universal sameness rebukes ideas about racial difference based on skin color, as he argues that "[r]ed, black, and white skins are all children of one and the same heavenly Father and of the same mother, Nature" (ix). So if Posthumus our stock," and a "brother," this characterization registers an ambivalence that suggests how, in Hayden White's terms, Europeans paradoxically imagined Indigenous people as both "continuous with that humanity on which Europeans prided themselves" and as "existing contiguously to the Europeans" (193-94). Indeed, as Shari M. Huhndorf and Philip J. Deloria have argued, colonial representations of the Indian "Other" grew increasingly complex in the nineteenth century but had always

By rooting this universalism in a narrative of "development," 
however, Posthumus makes a common assumption about a temporal difference between Indigenous people and Europeans. Citing David Hume's Natural History of Religion (1757), Posthumus argues that the Sauk people's belief in appeasing the spirits of Rock Island is analogous to the domestic deities of ancient Persians, Jews, pagans, and Christians (Levensgeschiedenis 135). What is ostensibly an argument to validate Sauk customs echoes a colonial imaginary in which American Indians belong to an ancient or even "mythical past" (Flint 5). However, his analysis of native people's relation to temporality is not simply a denial of Native people's place in the modern world, and Posthumus identifies two modes by which Black Hawk tells historical time. He distinguishes between the first seven pages, in which Black Hawk narrates the history of the Sauk people through an account of his ancestors, and the remainder of the text, which chronicles his own military and political experiences. The opening section, Posthumus argues, represents "the hazy and indeterminate recollection of [Black Hawk's] ancestors," and as such it "floats around more in the realm of myths and sagas, which precedes the historical," relating only "the most important events" by following "the whims of an uncertain imagination" (Levensgeschiedenis 126). But if the opening passages are "hazy" and "uncertain," Posthumus does not therefore discredit them as historical knowledge. To the contrary, he suggests that this part of the book is similar to "biblical history," with a reckoning of time that "keeps to the main events" but also "serve[s] as a light and guide in pursuit of the truth in all her generality and uniformity" (126). Moreover, he suggests that this pursuit of "truth" continues when Black Hawk "offers us his own facts and experiences," since then he relates "the historical truth, in accordance with the unchanging order of nature" (126; emphasis mine). In other words, both parts of Black Hawk's narrative offer historical insight: one relates to a form of biblical time and is difficult to locate historically, while the other exists in the "order of nature" and can be observed in the physical world. Both, he implies, should be taken seriously as a source of knowledge.

Here Posthumus trades in on a Romantic belief that the textual encounter with Indigenous people allowed Europeans to "benefit from contact with their temporal other" (Sorensen 77), to connect with notions of virtue and truth beyond the bounds of historical time. This means that throughout Levensgeschiedenis his métier as a Protestant 


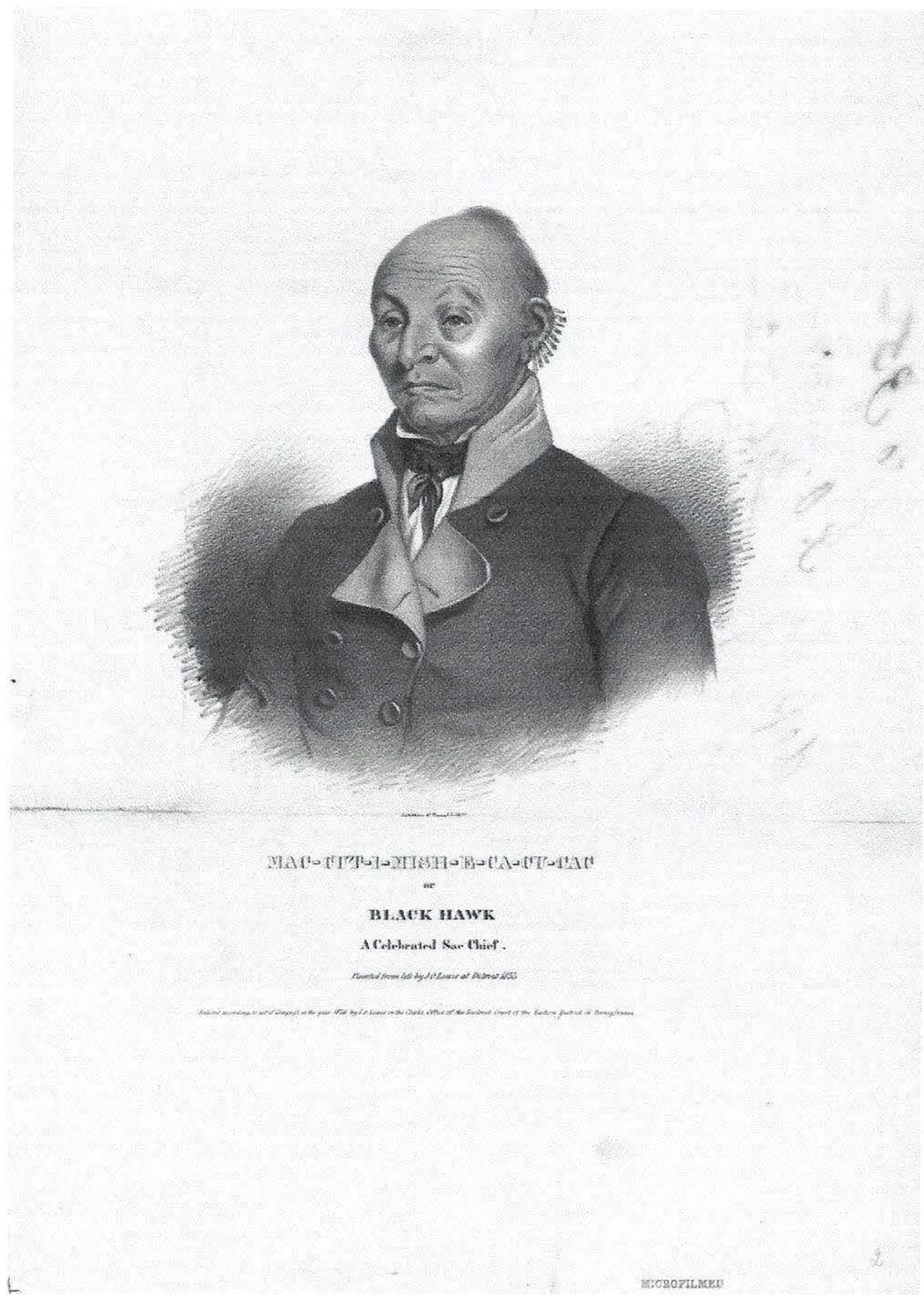

Fig. 3. James Otto Lewis, Mac-cut-i-mish-e-ca-cu-cac or Black Hawk, a Celebrated 
country preacher is clearly on display. Presenting Black Hawk's narrative as an object of scholarly exegesis, Posthumus highlights moments that serve as morality tales or opportunities for religious insight. For instance, he criticizes Christians who presume that they are the "high nobility of God's race," admonishing readers that they can only be "worthy" of this title "if we recognize our brothers in all peoples, and treat them as brothers, just as God treats us all like his children" (Levensgeschiedenis ix). When Black Hawk explains the duty of sharing resources with those in need, Posthumus's endnote suggests that Black Hawk's reasoning is "much more grounded and wholesome than that of many Christians and very learned theologians among them" (134). In another passage, Black Hawk explains the different Sauk ceremonies to honor the Great Spirit and how his own practices of worship differ from those of others in his nation. Here Posthumus comments that Black Hawk "teaches us, that he possessed common sense and even independence of thought. Man's dependence on the good Spirit, and his obligation to be grateful for all the good gifts received from that Spirit, how vividly are they recognized here! to the embarrassment even of many Christians, and rendered in short, fully human strokes" (138). Trading in on the rhetorical power of the Indian as a trope in transatlantic discourse, Levensgeschiedenis exhibits the lens of a small-town Protestant pastor who held up Black Hawk's actions to communicate the ideals and shortcomings of selfprofessed Christians. $^{5}$

"DEPLORABLE EUROPEAN STATESMANSHIP":

STATE POWER, MIGRATION, AND LIBERAL GUILT

If Rinse Posthumus approached Black Hawk's narrative from a Protestant theological standpoint, there was also a political dimension to the moralizing bent of his commentary. Enacting a sympathetic identification with Black Hawk and the Sauk people, Posthumus castigates the manipulations of European empires leading up to the Black Hawk War. In the introduction he explicates Black Hawk's account of intertribal wars and the War of 1812 by refusing the stereotype that this warfare was a symptom of American Indian savagery. Instead, he argues that it was the result of the geopolitical designs of "civilized" European empires. Black Hawk and his followers are not the instigators of war but 
dupes in an imperial power play that was marked by European lies and manipulation:

The unwitting Indians, whose unrestrained passions were kindled in all kinds of manners by the lust for profit and domination on the part of the Christians, thus fell into the traps of a deplorable European statesmanship and in ignorance plunged themselves into ruin on behalf of their false friends. They pushed these undeveloped sons of nature to commit all kinds of cruelties, only to mock them on the same account later, by depicting them as devils or even punishing them. So it also went in the war of BLACK HAWK and his band. (Levensgeschiedenis Xv)

Establishing continuity between the imperialism of the War of 1812 and the "unrestrained," "unwitting," and "undeveloped" American Indian.

In this commentary, Posthumus recognizes the moral economies that intellectual" through an ability to imagine the pain and emotions of others (12). This position became a key trope in the Enlightenment- 
this history, and Laura M. Stevens demonstrates how the rhetoric of "the poor Indians" influenced religious debates about inequality and reform in the Atlantic world (33). Through such rhetorical and intellectual traditions, the representation of Indians became a convenient vehicle for expressing sympathy toward people on the receiving end of global injustice.

Posthumus's sympathy toward the Sauk people bespeaks his political engagement and brought Black Hawk's account of Sauk dispossession into current discourses on the role of government in protecting individual and group rights. Posthumus's political commitment intensified with the Dutch government's inadequate response to the failed harvest of 1845 , which led to food riots that spread across the country, including the provinces of Friesland and Groningen (Kuiken 186). Although he eschewed the label of socialist or communist (Posthumus, Over 10), as a country pastor living in a region undergoing rapid economic decline, he was deeply concerned with class struggles in the Netherlands, and his political beliefs made him "one of the most spirited and radical figures" within the Reformed Church (Jensma 43; translation mine). He was aligned with the movement of liberalism in the Netherlands and became editor of the liberal newspaper Provinciale Friesche Courant in 1842 (Kuiken 175) and associated with the liberal politicians Dirk Donker Curtius and Harmanus Klaasesz, the latter of whom led the liberal movement in Posthumus's home municipality of Westdongeradeel (Breuker 14-16). Whereas liberalism in Europe is often associated with free trade and laissez-faire economics, Dutch liberals championed a movement away from monarchal power, government oversight on the part of the parliament, an expansion of the suffrage, and the legal protection of civil rights (Kuiken 179). Liberals formed an increasingly influential coalition between the landed gentry, elite farmers, and intellectuals who criticized the policies of King William II and advocated for constitutional reforms on national, provincial, and local levels.

Although Levensgeschiedenis does not lay out a coherent vision of Posthumus's liberal politics, his annotations pause on the role of both government and free citizens in Black Hawk's account of the 1832 war, casting the Sauk people as victims of an imperial power play, as well as rampant greed. First, he criticizes the imperial governmental manipulations that divided the Sauk Nation, leading some of them to fight with Black Hawk while the majority acquiesced to removal 
from the village of Saukenuk to reservations west of the Mississippi. Posthumus explains that "[t]he division within his tribe, the work of European and American statesmanship and interference, became, as it was intended, the cause of his being weakened to a state of complete defenselessness. Divide et impera: divide and conquer, which had been used so successfully so many times, worked according to plan again here, in the interest of the whites" (Levensgeschiedenis 143). But if Posthumus blames European governments for their destructive impact on Indigenous resistance movements, he goes on to argue that Sauk dispossession overall was the work of settlers acting in the absence of government oversight. As Roxanne Dunbar-Ortiz notes, the Black Hawk War was essentially "a slaughter of Sauk farmers" (111), and Black Hawk's narrative intensifies when white settlers begin to destroy the Sauk people's cornfields. At this point, Posthumus notes that " $[t]$ he abuses, to which Black Hawk's tribe, by way of their violent expulsion from his village, fell victim, was surely more the work of greedy planters than of the North-American government, which did mislead [them] but which would have acted more justly on better information" (Levensgeschiedenis 143). These annotations accentuate how Black Hawk exposes the tensions between the individual freedoms of white settlers and the danger of those freedoms affecting vulnerable populations. The violence of the Black Hawk War, Posthumus emphasizes, happened primarily not because of the policies of the federal government but rather because of the actions of greedy settlers who operated outside of its purview.

The scholarly apparatus in Levensgeschiedenis thus brings out a strand of the narrative that reflects on the relation between settler colonialism and the working of state power. On the one hand, Posthumus underestimates the extent to which the Black Hawk War was enabled by federal policymakers who sanctioned the organization of a volunteer army against the Sauk Nation and carried out removal policies that shaped US-Indian relations on a continental scale. On the other hand, he recognizes the logic by which settler colonialism was, in Patrick Wolfe's terms, a "decentered" process that not only was effected through direct governmental action but also depended on a "range of agencies from the metropolitan centre to the frontier encampment" (393). In other words, Posthumus underscores how Black Hawk's narrative mediates between a critique of state power as it overreaches through direct military inter- 
vention and as it fails to act to guarantee justice and protect the rights of an oppressed people. In all its shortcomings, he suggests, the "highest government" should not be seen as the only source of social injustice, and indeed it is the actions of the individual settler colonists that Posthumus condemns most vehemently: "Where Black Hawk complains multiple times of the lack of a fixed standard of justice and injustice among the whites, this came from his lack of understanding that among them the standard of egotism and self-interest is substituted" (Levensgeschiedenis 144). In Black Hawk's account of Sauk dispossession, then, Posthumus emphasizes how settler expansion-beyond the reach of government oversight-is unmoored from questions of civic duty and social justice and beholden only to individual economic interests.

In short, Posthumus amplifies the Life's perspective on the relation between government and free enterprise in a history of oppression. This perspective also negotiates political anxieties about the role of government at a time of economic crises and rural poverty in the Netherlands. Posthumus suggests that the book's critique of Sauk dispossession-in which the actions of private citizens and lower-level officials played a defining role-mirrors the problems of government on the other side of the Atlantic: "In Europe also, is there not all too frequently very much evil and misery accomplished by private citizens, or subordinate members of government, or councils [collegien], of which the highest government remains uninformed because people keep her uninformed about it?" (Levensgeschiedenis 143-44). Defending the role of federal government, he concludes that "[i]t is equally foolish and bad to regard the highest government as the cause of all evil in a society and blame her, as it is to worship her" (144). His inferences from the Black Hawk War about the nature of government reflect Helena Rosenblatt's argument that, historically speaking, political liberals were not necessarily for or against a strong role for government; instead, most were "moralists" who tied ideas about individual rights and freedom to a regard for civic duty and "questions of social justice" (4). And if Posthumus is critical of imperial government, he also believes that injustice and dispossession can result from a lack of government oversight. Black Hawks history thereby dramatizes a key tension that liberal intellectuals such as Posthumus negotiated: that the task of government is to allow citizens to pursue their individual freedom, but that government is also obliged to curb those freedoms when they pose a threat to the rights of others. 
But for Posthumus, this debate on state power also related to the intertwined issues of settler colonialism in North America and transatlantic immigration. In the same year that Posthumus worked on the translation of the Life, he published a tract laying out a vision for the role of government in ameliorating "poverty and impoverishment" in the Netherlands. ${ }^{6}$ Placing his own region of northern Friesland in a larger European context, Posthumus locates the causes of poverty in overpopulation, taxes on daily food items, and the unavailability of "useful labor" (Over 13). Crucially, Posthumus envisions transatlantic migration as an important recourse, especially for Dutch farmers. His solution to overpopulation is to reclaim lands domestically for agricultural use, for laborers to move to the Dutch colonies in Indonesia, Surinam, and the Caribbean, and for the government to incentivize the immigration of farmers to North America (21-24). As to the latter, he explains: "Beyond our native country, to the west, lies North America, a country whose vast yet still uncultivated fields clamor for us to call industrious populators [bevolkers] to labor there under a free government for themselves, as people and citizens. There exists for each who is able and willing, abundant opportunity ... to perfect himself through his serviceable labor, which is becoming increasingly difficult over here" (22). In the United States, he argues, farmers would stand to benefit from its liberal government, noting similarities with the Dutch Republic before the Batavian Revolution: "There, where the form of government has so much of the good things of the old republic of the Netherlands before 1795, freedom and development are inherent in the people's nature and the wrongs that spring from them. There is youth and energy in its citizens, as opposed to European senescence and weakness. There, freedom of movement rules ... in social life" (22). Whereas in Levensgeschiedenis Posthumus locates the cause of Sauk dispossession in the actions of "greedy planters" acting outside of the purview of federal government, here he champions a liberalism that safeguards the "freedom of movement" of its citizens. And if Posthumus is pessimistic about the possibility of liberal government in the Netherlands, he imagines its foothold in the US republic as a safety valve for economic crises and class struggles at home.

Of course, Posthumus's tract on Dutch poverty should not be read directly into his commentary on Black Hawk's text, but it underscores how he saw the issue of transatlantic immigration as bound up with a 
crisis of poverty in the Netherlands and the promise of liberal government in the United States. In Levensgeschiedenis, however, he remains silent on this issue: the sole reference to Dutch immigration is the dedication to his friend Klaas Janszoon Beukma, "a citizen of North America, where justice and freedom have their temple and the people's happiness is rapidly advancing and maturing" (Levensgeschiedenis v-vi). So although Posthumus worked on his translation during the peak years of immigration to the United States, he does not explicitly connect Dutch migration to the issue of settler colonialism in the American Midwest (in the same way that his critique of empire does not extend to Dutch plantation colonialism in Indonesia, Surinam, and the Caribbean). Perhaps in his appeal to a universal brotherhood, Posthumus called on potential immigrants to be more ethical in their relation to Indigenous populations than the "greedy planters" in Black Hawk's narrative, but his appeal to cross-cultural sympathy is ultimately a limited one in a settlercolonial situation where the central dynamic is the taking of Indigenous lands. After all, the increased emigration from Friesland and Groningen to the United States depended on the extinguishing of Indigenous land title in present-day Illinois and Iowa, a region that had been opened up for white settlement through the Black Hawk War, the repeated displacement of the Sauk and Meskwaki people, and, by 1847 , their removal to Indian Territory. And if the ideology of American liberal government held implications for Dutch farmers seeking to immigrate, it did all the more so for Indian nations that bore the brunt of European proimmigration discourses. In this respect, Posthumus's analysis of Black Hawk's text expresses an ambivalent intellectual standpoint, one that is oriented to a cosmopolitan worldview but dedicated to local economic concerns, espouses ideals of cultural relativism but is steeped in Protestant moralizing, and is critical of empire but ultimately silent on the role of Dutch colonialism in producing global inequalities.

\section{CONCLUSION}

In making my case for the political dimensions of the Dutch edition of Black Hawk's Life, I do not mean to suggest that Levensgeschiedenis was a thinly veiled treatise on liberal government or that Rinse Posthumus subsumed its narrative only to advance his own intellectual agenda. Perhaps he simply considered the book a curiosity, a piece of Americana 
that would introduce Dutch readers to the recent history and geogra-

not eclipse Black Hawk's own account of his experiences. In fact, when

the narrative turns to the US military campaign against the Sauk people in 1832, Posthumus scales back his annotations: "This last part of Black Hawk's story gives little reason for commentary. He recounts so clearly 6 and impartially his experiences with and actions against the whites $7 \mathrm{t}$ that every reader, upon due consideration, can contentedly judge it for 8 themselves" (Levensgeschiedenis 143). By putting Black Hawk forward as an "impartial" critic of this history, Posthumus amplifies his rhetoric by retreating as the textual explicator. In Black Hawk's account of Sauk dispossession, then, Posthumus also saw a narrative that might be trusted without mediation, declaring himself a faithful reader of his text.

Without Black Hawk ever knowing it, his autobiography became part of a Frisian-Dutch literary culture in which it augmented the sermons Posthumus delivered from his pulpit and the pamphlets he circulated. But it would be too simple to dismiss Posthumus's editorializing as just one more variation on the narrative of the noble savage or the "poor Indian." Nor did Posthumus adopt Black Hawk as merely a romantic emblem for his own Frisian ethnolinguistic nationalism. In his own way, the Frisian pastor took Black Hawk seriously as a critical voice in a debate informed by political liberalism about the role of the state in global systems shaped by inequality and (forced and voluntary) population movements. Still, if the book presents Black Hawk as an authority on a history of dispossession, it is also a reminder of how fraught and limiting that role was for authors of Native American literature. Posthumus both amplified and delimited the resonance of Black Hawk's critique, engaging with the history of settler colonialism in Indigenous homelands while remaining silent on the ways that Native people were affected by Dutch immigration during this very decade. Perhaps it is fair to say that Posthumus's sympathetic treatment of Black Hawk mirrors the cultural work of German enthusiasts who, as Lisa King argues, turned to representations of Indianer to identify as "fellow underdogs or victims in a brotherhood with Indigenous peoples" (29-30) in ways that both challenged and denied their own colonial presence in the world.

The transatlantic adaptation of Indigenous writing adds an important dimension to the literary history of Native North America, laying bare how Native and non-Native authors reckoned in overlapping ways with 
the fact that Indigenous dispossession was inextricably tied to economic and political developments in Europe. Since the beginning of colonial contact, Indigenous people shared their perspectives on the workings of empire in scenes of diplomacy, in cultures of letter-writing, on the lecture circuit, and, like Black Hawk, in a transatlantic market for printed books. As a growing body of work in transnational Indigenous studies has shown, these efforts were not beholden to national or linguistic boundaries, and in this cultural exchange, Indigenous critiques of colonialism intersected with broader political debates about state power and popular resistance. Dialogic texts such as Rinse Posthumus's Levensgeschiedenis tell us how these critiques fashioned more than a generic discourse about the Indian as they became part of an intellectual reckoning with transatlantic migration in a connected world economy. Taking up these concerns in a time of crisis and revolutionary sentiment, Levensgeschiedenis van Ma-ka-tai-me-she-kia-kiak testifies to the unbounded horizons of American Indian writing.

FRANK KELDERMAN is an assistant professor of English at the University of Louisville, where he teaches American Indian and early American literatures. His research focuses on the collaborative dimensions of nineteenth-century Native writing and oratory. He is the author of Authorized Agents: Publication and Diplomacy in the Era of Indian Removal (SUNY Press, 2019).

\section{NOTES}

I want to thank Phillip Round, Joseph Turner, and two anonymous reviewers for their helpful suggestions.

1. My conclusion that Rinse Posthumus's Levensgeschiedenis is the first foreign translation of a Native-authored book is based on my own survey of secondary scholarship, catalogs, and databases. This survey is not foolproof, and I hope that other scholars will point out earlier examples. I admit that my definition of the term "foreign translation of a Native-authored book" is somewhat limited: I here mean a full-length printed book by a Native American author that has been translated into a language other than English or the Indigenous languages of North America. This means that my definition excludes, for instance, hymn books compiled by Indigenous writers that were translated into Indigenous languages. Furthermore, since the original version of Black Hawk's text was interpreted from Sauk to English, this first edition can be regarded as a "foreign translation" in its own right. Indeed, the very question of how we think about the term "foreign translation" in early Native American literature should be the subject of further discussion.

2. It is worth noting here that between 1835 and 1838 , Beukma authored a mul- 
tivolume account of his immigrant experience for Dutch reading audiences, which suggests an increased interest in immigration to North America (Breuker 13).

3. All Dutch-to-English translations of Rinse Posthumus's introduction and endwords.

4. An Algonquian language, the Sauk language is closely related to the Meskwaki

5. My use of the word Indian in italics is indebted to Gerald Vizenor's use of the term in Manifest Manners, which I take to denote a colonial simulation of Native people in global discourse, one that is mobile and emptied of Indigenous peoples active presence (11).

6. The title of Rinse Posthumus's 1846 tract is Over de al te groote armoede en verarming in Nederland, en de middelen daartegen, which can be translated as "On the all-too-great poverty and impoverishment in the Netherlands, and the remedies against them."

\section{WORKS CITED}

Black Hawk. Life of Ma-ka-tai-me-she-kia-kiak, or Black Hawk: Embracing the

Tradition of His Nation-Indian Wars in Which He Has Been Engaged-Cause of

Joining the British in Their Late War with America, and Its History-Description

of the Rock-River Village-Manners and Customs-Encroachments by the Whites,

Contrary to Treaty-Removal from His Village in 1831. With an Account of the

Cause and General History of the Late War, His Surrender and Confinement at

Jefferson Barracks, and Travels through the United States. Edited by John Barton

Patterson. J. B. Patterson, 1833.

Bolz, Peter. "Life among the 'Hunkpapas': A Case Study in German Indian Lore." Indians and Europe: An Interdisciplinary Collection of Essays, edited by Christian F. Feest, U of Nebraska P, 1999, pp. 475-90.

Breuker, P. H. "Rinse Posthumus syn plak yn it opkommende liberalism to Dokkum en Westdongeradiel." Us Wurk: Journal of Frisian Studies, vol. 54, no. 1-2, 2005, pp. 3-23. https://ugp.rug.nl/uswurk/article/view/27392.

Deloria, Philip J. Playing Indian. Yale UP, 1998.

Dunbar-Ortiz, Roxanne. An Indigenous Peoples' History of the United States.

Ellison, Julie. Cato's Tears and the Making of Anglo-American Emotion. U of Chicago

Flint, Kate. The Transatlantic Indian, 1776-1930. Princeton UP, 2009.

Halbertsma, Joost Hiddes. Rinse Posthumus, in leven kerkleraar onder de hervormde 
Helton, Tena. "What the 'White Squaws' Want from Black Hawk: Gendering the Fan-Celebrity Relationship." American Indian Quarterly, vol. 34, no. 4, 2010, pp. $498-520$.

Huhndorf, Shari M. Going Native: Indians in the American Cultural Imagination. Cornell UP, 2001.

Jensma, Goffe. Het rode tasje van Salverda: Burgerlijk bewustzijn en Friese identiteit in de negentiende eeuw. Fryske Akademy, 1998.

King, Lisa. "Revisiting Winnetou: The Karl May Museum, Cultural Appropriation, and Indigenous Self-Representation." Studies in American Indian Literature, vol. 28 , no. 2, 2016, pp. 25-55.

Krabbendam, Hans. Freedom on the Horizon: Dutch Immigration to America, 18401940. Eerdmans, 2009.

Krupat, Arnold. For Those Who Come After: A Study of Native American Autobiography. U of California $\mathrm{P}, 1989$.

- "Patterson's Life, Black Hawk's Story: Native American Elegy." American Literary History, vol. 22, no. 3, Oct. 2010, pp. 527-52.

Kuiken, Cornelis Jan. Het bildt is geen eiland: Capita cultuurgeschiedenis van een vroegmoderne polder in Friesland. Nederlands Agronomisch Historisch Instituut, 2013 .

Lyons, Scott Richard. "Migrations to Modernity: The Many Voices of George Copway's Running Sketches of Men and Places, in England, France, Germany, Belgium, and Scotland" The World, the Text, and the Indian: Global Dimensions of Native American Literature, edited by Scott Richard Lyons. State U of New York P, 2017, pp. 143-214.

Multatuli, pseud. Eduard Douwes Dekker. "Japansche gesprekken." Verzamelde werken van Multatuli: Eerste naar tijdsorde gerangschikte uitgave, bezorgd door zyne weduwe. Vol. 10. Elsevier, 1889.

Parins, James W. John Rollin Ridge: His Life and Works. U of Nebraska P, 2004.

Penny, H. Glenn. Kindred by Choice: Germans and American Indians since 1800 . U of North Carolina P, 2013.

Posthumus, Rinse. Brief over eenige gebreken en misbruiken in ons hervormd kerkbestuur en wetgeving, gerigt aan zijne hervormde medeleeraars. J. Oomkens, 1831.

- Een woord ter opwekking van den volksgeest in het zwijgend Friesland, met eene opdragt aan den W. E. Z. G. Heer en Mr. Dirk Donker Curtius, advokaat te' 'S Gravenhage. D. Meindersma, 1840.

- Levensgeschiedenis van Ma-ka-tai-me-she-kia-kiak, of Zwarte Havik, opperhoofd van den stam der Sac-indianen in Noord-Amerika, met een berigt van de godsdienstige denkwijze, zeden en gebruiken, van dien stam; volgens zijne eigene opgave aan den tolk der Sac-en Fox-indianen, en door dezen in het Engelsch overgebragt. D. Meindersma, 1847.

- Over de al te groote armoede en verarming in Nederland, en de middelen daartegen. D. Meindersma, 1840.

- Prieuwcke fen Friesche Rijmmelarije. J. Oomkens, 1824. 
Posthumus, Rinse, and Montanus Hettema. Onze reis naar Sagelterland, benevens deszelfs geschiedenis, eene beschrijving van den aard, de zeden, de gewoonten enz. van deszelfs bewoners en een korte schets en woordenlijst van hunne taal. G. Ypma, 1836.

Rifkin, Mark. "Documenting Tradition: Territoriality and Textuality in Black Hawk's Narrative." American Literature, vol. 80, no. 4, 2008, pp. 677-705.

Rivett, Sarah. Unscripted America: Indigenous Languages and the Origins of a Literary Nation. Oxford UP, 2017.

Rosenblatt, Helena. The Lost History of Liberalism: From Ancient Rome to the Twenty-First Century. Princeton UP, 2018.

Round, Phillip H. Removable Type: Histories of the Book in Indian Country, 16631880. U of North Carolina P, 2010.

Scheckel, Susan. The Insistence of the Indian: Race and Nationalism in NineteenthCentury American Literature. Princeton UP, 1998.

Sorensen, Lise. "Savages and Men of Feeling: North American Indians in Adam Smith's The Theory of Moral Sentiments and Henry Mackenzie's The Man of the World." Native Americans and Anglo-American Culture, 1750-1850: The Indian Atlantic, edited by Tim Fulford and Kevin Hutchings, Cambridge UP, 2009, pp. 74-93.

Stevens, Laura M. The Poor Indians: British Missionaries, Native Americans, and Colonial Sensibility. U of Pennsylvania P, 2004.

Sweet, Timothy. "Masculinity and Self-Performance in the Life of Black Hawk." 19 American Literature, vol. 65, no. 3, 1993, 475-99. 20

Swierenga, Robert P. Pioneers and Profits: Land Speculation on the Iowa Frontier. $\begin{array}{lr}\text { Iowa State UP, } 1968 . & 22\end{array}$

Vizenor, Gerald. Manifest Manners: Narratives on Postindian Survivance. Lincoln: U 23 of Nebraska P, 1994.

Weaver, Jace. The Red Atlantic: American Indigenes and the Making of the Modern World, 1000-1927. Chapel Hill: U of North Carolina P, 2014. 25

White, Hayden. "The Noble Savage Theme as Fetish." Tropics of Discourse: Essays in 26 Cultural Criticism. Johns Hopkins UP, 1978, pp. 183-96. 27

Wolfe, Patrick. "Settler Colonialism and the Elimination of the Native." Journal of 28 Genocide Research, vol. 8, no. 4, 2006, pp. 387-409. 29

Wumkes, G. A. "Rinse Posthumus." Nieuw Nederlands biografisch woordenboek, vol. $\begin{array}{ll}\text { 3, edited by P. J. Blok and P. C. Blokhuysen, Sijthoff, 1914, pp. 988-89. } & 30 \\ \text { ntop, Susanne. Colonial Fantasies: Conquest, Family, and Nation in Precolonial } & 31\end{array}$ Germany, 1770-1870. Duke UP, 1997. 